\title{
Frugivory in Lacistema hasslerianum Chodat (Lacistemaceae), a gallery forest understory treelet in Central Brazil
}

\author{
Melo, C.* and Oliveira, PE.* \\ Instituto de Biologia, Campus Umuarama, Universidade Federal de Uberlândia, \\ Rua Ceará, s/n, CEP 38400-902, Uberlândia, MG, Brazil \\ *e-mail: celine@inbio.ufu.br, poliveira@ufu.br \\ Received October 8, 2007 - Accepted February 7, 2008 - Distributed February 28, 2009
}

(With 2 figures)

\begin{abstract}
The objectives of this study were to know and to characterize the behavioural patterns of frugivorous birds in Lacistema hasslerianum. The study was carried out in the Panga Ecological Station (Uberlândia, Minas Gerais State). During the frutification time (September-October), L. hasslerianum was observed for 31.25 hours and received 58 visits by five species of birds. Tyrannidae was the best represented family ( 2 species). Pipridae was the most frequent visitor in L. hasslerianum (68.97\% of visits). The number of consumed fruits was correlated with the time of permanence on the plant. The main foraging tactic was "Stalling" (58.62\%) and the most frequent fruit consumption strategy was "swallower" (45.25\%), which indicates a high seed dispersal potential. Antilophia galeata (Pipridae), although a territorial bird, presented the best dispersal efficiency for Lacistema hasslerianum, because of its consumption rate (2.82 whole fruits consumed/minute).
\end{abstract}

Keywords: birds, frugivory, Lacistema hasslerianum, Cerrado.

\section{Frugivoria em Lacistema hasslerianum Chodat (Lacistemaceae), uma arvoreta de subbosque de Mata de Galeria no Brasil Central}

\section{Resumo}

Os objetivos deste estudo foram conhecer e caracterizar o padrão comportamental das aves frugívoras em Lacistema hasslerianum. O estudo foi realizado na Estação Ecológica do Panga (Uberlândia-MG). Durante a época de frutificação (setembro-outubro), L. hasslerianum foi observada por 31 horas e 15 minutos e recebeu 58 visitas de cinco espécies de aves. Tyrannidae foi a família mais representativa ( 2 espécies), Pipridae, a família mais frequente $(68,97 \%)$. O número de frutos consumidos foi correlacionado com o tempo de permanência na planta. A principal tática de forrageamento utilizada pelos visitantes de L. hasslerianum foi "vôo" $(58,62 \%)$ e a estratégia de consumo do fruto predominante foi "engolidor" (45,25\%), o que indica um elevado potencial de dispersão. Antilophia galeata (Pipridae), apesar de territorialista, apresentou a maior eficiência de dispersão para L. hasslerianum devido à sua taxa de consumo (2,82 frutos consumidos inteiros/minuto).

Palavras-chave: frugivoria, Lacistema hasslerianum, Cerrado.

\section{Introduction}

The role of birds as dispersal agents and their influence on seed germination have been associated with environmental regeneration and maintenance (Argel-deOliveira et al., 1996; Guedes et al., 1997; Oliveira and Paula, 2001). In this sense, the interactions of frugivorous birds with zoochorous plants are of great interest, especially where this dispersion type is predominant, as in forest formations of the Cerrado Bioma, the Neotropical savanna areas of Central Brazil (Melo et al., 2003).

Dispersal effectiveness is defined as the contribution of the dispersal agent to the plant reproduction and depends on two different parameters, the quantity and quality of seed dispersal (Schupp, 1993), which results from factors such as time of visit, number of fruits consumed, disperser behaviour (handling) and deposition of the intact seeds on appropriate sites and choice of mature fruits (Herrera, 1982; Motta-Júnior and Lombardi, 1990; Schupp, 1993; Galetti and Pizo, 1996; Murali, 1997). 
However, typical dispersal agents may be deficient in their dispersal ability (Schupp, 1993). Several factors interfere in the choice of fruits, such as colour, accessibility, nutrition value (Snow, 1971), shape, size, position of the fruits (Foster, 1977), abundance (Snow, 1971; Moermond and Denslow, 1983; Levey et al., 1984) and size of the beak of the dispersal agent (Kantak, 1979). Such factors can lead to different ecological consequences under specific conditions. If there is a relative abundance of fruits, the frugivore may be able to move to areas with larger availability of resources (Foster, 1977; Levey et al., 1984) or make more restrictive choices (Moermond and Denslow, 1983). On the other hand, in periods of shortage, when mature fruits can be rare and in reduced amounts, this resource would be explored intensely, leading to an even faster decrease (Lambert and Marshall, 1991). The foraging tactics that determine the amount of fruits ingested in a certain period of time, as well as the consumption strategy will determine the role of the frugivore (disperser or predator).

The understory of tropical forests sustains a different fauna from the canopy, with species of birds restricted to these areas, to which understory plants are the largest source of resources (Gentry and Emmons, 1987). Although there is a prevalence of omnivorous and insectivorous birds out on the canopy, in the understory of tropical forests, the insectivorous species are dominant and they tend, furthermore, to suffer less seasonal oscillation (Greenberg, 1981). The largest consumption of fruits, including consumption by insectivorous and omnivorous species, has been typically associated with the time of reproduction of the birds and with opportunities due to availability of resources (Mikich, 2001). Considering the importance of the understory of forest physiognomies of the Cerrado region to the maintenance of the avifauna (Bagno and Marinho-Filho, 2001; Melo, 2003), there is a need for additional information on plant-frugivore interactions in these habitats. Some understory plant species can be important for local avifauna restricted to these habitats (Gentry and Dodson, 1987).

The objective of this study was to observe the frugivorous birds that consume Lacistema hasslerianum Chodat fruits, a common species in the understory of forests in the Triângulo Mineiro region, in central Brazil, in order to characterize and to compare the behaviour of the frugivorous birds with respect to foraging tactics and fruit consumption strategies. Such informations were further used to determine the main seed dispersers and to test the hypothesis that birds with more specialized frugivorous diets would present better fruit handling and consumption efficiency (number of fruits/time) besides rendering better seed dispersal for this understory tree.

\section{Material and Methods}

\subsection{Plant species and study area}

Lacistema hasslerianum is a shrub or treelet of the family Lacistemaceae. This family is considered rare in gallery forests of the Distrito Federal (Silva-Júnior et al., 2001), but it is one of the most abundant in the forest gradient of the Ecological Station of Panga, in Uberlândia, MG (Arantes, 2002). It is a typical species of Gallery and Mesophyllous forests, appearing mainly close to water courses. The fruiting period of L. hasslerianum is between September and December (Arantes, 2002) with a peak from mid-September to the beginning of October, when mature fruits are produced in larger quantities (Melo, 2003). The fruit is a dehiscent capsule with a red pericarp and a white aril surrounding the seed, a contrasting arrangement which is commonly associated with bird dispersed fruits. Average fruit (propagule) dimensions are $6.29 \times 3.53 \mathrm{~mm}$. Sugar concentration in the aril is ca. $15.5 \%$ (Melo, 2003).

The study was carried out in a Gallery Forest area in the Panga Ecological Station (PES) in Uberlândia-MG (19 09'-19 11'S and 48 23'-48 24'W; $800 \mathrm{~m}$ ), an area of 409.5 ha maintained by the Federal University of Uberlândia (Schiavini and Araújo, 1989). The climate of the area is seasonal with a rainy summer, between October and March, and a dry winter, between April and September (Rosa et al., 1991). The vegetation of the area is the Cerrado, open savanna formations, and forest gradients formed by the Gallery forests, Mesophyllous forest and Cerradão, denser woodlands. The studied gallery forest, along the Panga stream, has an area of approximately 15 ha (Arantes, 2002), with a continuous gradient to Mesophyllous forests and Cerradão (Schiavini, 1992).

Five focal individuals of Lacistema hasslerianum were observed in September and October of 2001. The observations were carried out between 6:45 AM and 5:30 PM, a period which was divided in 15 minutes observation intervals. A total of 31 hours and 15 minutes distributed along four weeks, the period of mature fruits presentation. Each 15 minutes interval was sampled four times up to 11:30 AM, and after this, there were made two samples per interval.

\subsection{Procedures}

The frugivorous birds that removed fruits (actually the diaspore was removed, which consisted of the seed plus the aril, but hereafter, we will refer to fruit removal for simplicity) from L. hasslerianum were observed. For each visit we registered: a. bird species, b. time of arrival and exit of the plant, c. number of consumed fruits, $d$. foraging tactics and e. consumption strategy. The foraging tactics were adapted from Moermond and Denslow (1985) as: "Stalling" (flight) when the bird collect the seed in flight, without landing on the plant or hovering in front of the fruit and "Picking" (settling), when the bird settled on the plant while removing and consuming the fruits.

The birds were classified for their fruit consumption strategies as suggested by Schupp (1993): "Swallower" - they gobbled up the whole fruit with the seeds; "Pulp consumer" - they removed pieces of the pulp, perforating or pecking the fixed fruit in the plant and "Predator" 
- when fruit consumption implied damage to the seeds and "Manipulator" - handled the fruits with the beak ingesting the juice and edible pulp, usually discharging entire seeds. The dispersal efficiency was inferred from the consumption rate, calculated as the average rate of whole fruits consumed per time of permanence on the plant (Motta-Júnior and Lombardi, 1990; Schupp, 1993).

The Spearman correlation (Zar, 1999) was used to verify if the time of permanence on the plant and fruit consumption varied linearly in the same magnitude. The index of diversity of Shannon-Weaver (J') (Zar 1999) was used to describe the contribution of the different bird species to the number of visits and consumed fruits. The Coleman Rarefaction (EstimateS 6.0) was made to estimate the species richness.

\section{Results}

There were 58 visits by five species of birds (Table 1), and in 55 visits the consumption of 138 fruits was observed. Tyrannidae was the most representative family with two species and Pipridae, the most frequent $(68.97 \%$ of the visits). The most frequent species were Antilophia galeata Lichtenstein, 1823 (Pipridae; $68.97 \%$ of the visits), a frugivore bird, and Saltator similis D'Orbigny and Lafresnaye, 1837 (Fringillidae; $22.42 \%$ of the visits), an omnivore specie (Tables 1 and 2). During the first two weeks of fruit presentation (observation sections 1-15), only these bird species were observed on L. hasslerianum. The remaining three species were recorded only during the third and fourth week of the study (observation sections 16-32) (Figure 1), when the number of fruits was already smaller and they were less explored by A. galeata ( $2.5 \%$ of the visits) and S. similis (23\% of the visits). The Coleman Rarefaction Curve shows the tendency to stabilization (Figure 1).

The visits occurred during the morning and afternoon, with two visitation peaks, between 7:00-8:00 AM and 12:00-3:00 PM (Figure 2). Antilophia galeata visited L. hasslerianum during the whole day (Table 1), and presented the largest visitation peaks, between 10:00 AM and 2:30 PM, even so it maintained ingestion rates relatively low (oscillating between 0.5 and 5.5 fruits/hour).

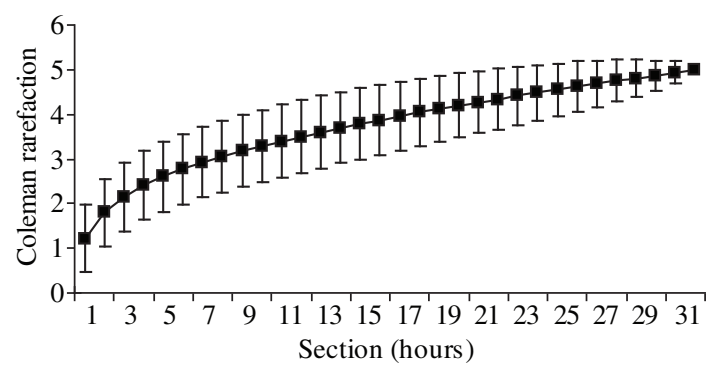

Figure 1. Coleman rarefaction curve (EstimateS 6.0) of bird species observed on L. hasslerianum after each observation hour.
Although it also visited $L$. hasslerianum throughout the whole day, Saltator similis presented smaller peaks, between 0.25 to 1.5 visits per hour (mean $0.35 \pm 0.53$ ), than A. galeata, that accomplished between 0.25 and 3.0 visits per hour (mean 1.21 \pm 0.93 ). Coereba flaveola Linnaeus, 1758 concentrated the visits and fruit consumption between 9:30 and 10:00 AM and its mean visiting time varied from 3.5 to 5.17 minutes (mean $4.08+0.94$ ).

In terms of consumption rate, $S$. similis and C. flaveola presented the more accentuated peaks with up to 8 (mean $2.53 \pm 1.56$ ) and 7 (mean $2.02 \pm 0.58$ ) fruits consumed per hour, respectively. Although A. galeata presented smaller peaks (5.5 fruits consumed per hour) than $S$. similis and $C$. flaveola, the oscillation in the consumption rate was smaller (mean $1.81 \pm 1.57$ ). In spite of the number of fruits consumed by $S$. similis $(\mathrm{N}=51)$ having been similar to those consumed by A. galeata $(\mathrm{N}=53)$, these species were different in terms of consumption strategy. Antilophia galeata generally gobbled the whole seeds (98.11\%), and S. similis destroyed them $(90.19 \%)$ (Table 2). Coereba flaveola consumed the aril only, without removing the seeds from the plant $(\mathrm{N}=28$ fruits consumed). The number of consumed fruits was positively correlated with the time of permanence of the bird on the plant $\left(\mathrm{r}_{\mathrm{s}}=0.8656 ; \mathrm{gl}=25 ; \mathrm{p}<0.00001\right)$. In most of the observed visits (72.4\%), there was consumption of one or two fruits.

Antilophia galeata presented the greatest fruit consumption rate (2.82 fruits whole per minute of visit) which therefore, possessed the largest dispersal efficiency. Although the rate of fruit consumption of $S$. similis was larger (4.9 fruits per minute of visit) than A. galeata, this species behaved as predator of most of the consumed fruits $(88.5 \%)$, because when consuming the fruits, the seeds were triturated before ingestion. This was confirmed by direct observation of seedling handling by the birds and fragments of the seeds discarded during foraging bouts. During the observed visits, only five fruits

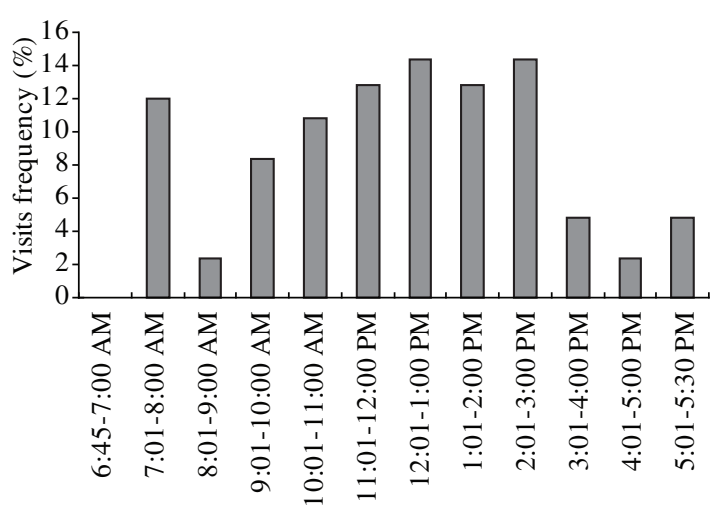

Figure 2 . Frequency of visits by birds throughout the day on L. hasslerianum. 

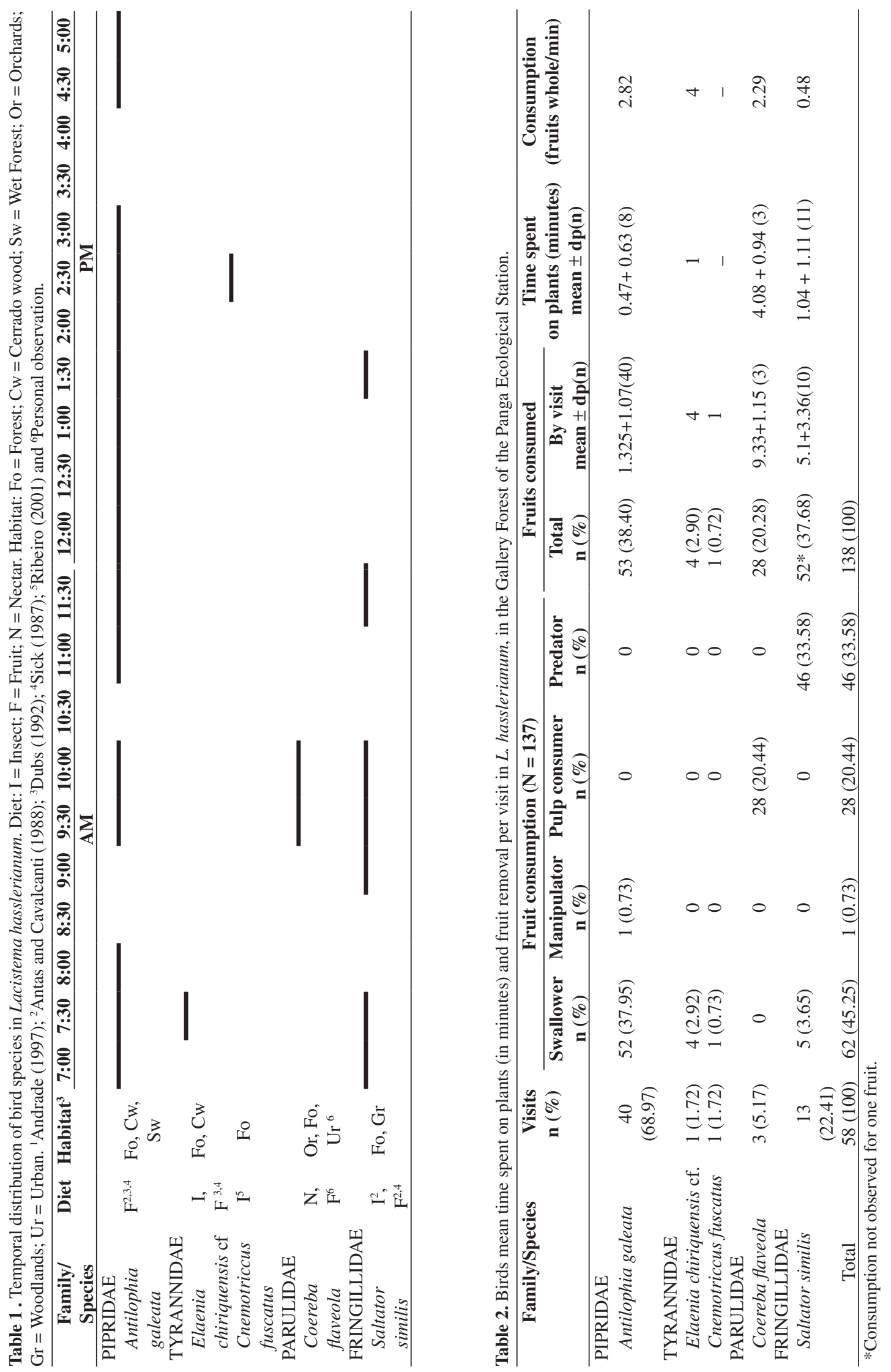
were consumed intact by $S$. similis, which represents a whole fruit consumption rate, and potential dispersal, of only 0.48 fruits per minute.

In most of the visits (69.09\%), a single fruit was consumed, and the "Stalling" (flight) foraging tactic was the most used $(58.62 \%)$. The "Swallow" consumption strategy was the most commonly used $(45.25 \%)$ followed by the "Predator" one $(33.58 \%)$, which was exclusively used by $S$. similis.

The number of bird visits to L. hasslerianum was more heterogeneous $\left(J^{\prime}=0.54\right)$ than the fruit consumption by frugivorous birds $\left(\mathrm{J}^{\prime}=0.74\right)$. This implies that, although the visits oscillated throughout the day, presenting peaks, fruit consumption did not oscillate so intensely.

\section{Discussion}

The fruit of L. hasslerianum can be considered medium sized (as defined by Kantak, 1979). Its shape and size can favor the consumption by smaller frugivorous birds such as A. galeata, but they can also be used by less specialized birds. In this same area, a study with Faramea cyanea (Melo et al., 2003) presented different results, with the prevalence of omnivorous species of Turdidae. As the handling of the fruits depends on its shape and size (Foster, 1977), larger fruits such as the one of $F$. cyanea, can restrict the consumption by some smaller frugivores due to the difficulty of gobbling up the whole fruit (Melo, 2003).

Another aspect is the relationship between the nutritious reward and fruiting period. The complete nutritional composition of L. hasslerianum is still unknown. We do know that L. hasslerianum presents a peak in the end of the dry season and beginning of the rainy season, and sugar content of $15.5 \%$, which is higher than other species in the area, such as F. cyanea, which offers fruits at the beginning of the dry season and Erythroxylum subracemosum and Neea hermafrodita which offers fruits at the middle of rainy season (Melo, 2003). The strategy to alternate fruiting peaks can also be advantageous for the maintenance of the dispersal agents in the area (Talora and Morellato, 2000; Arantes, 2002).

Birds stayed for a relatively short time on L. hasslerianum. This behaviour characterizes them as efficient seed dispersers, because it decreases the chance of regurgitated the seeds under the mother-plant (MottaJúnior and Lombardi, 1990). Despite the high frequency of visits by omnivorous birds, the frugivore A. galeata (Marini, 1992) presented the best dispersal potential: the largest amount of fruits consumed in a given time.

The consumption efficiency indicates the dispersal potential of the frugivore, once the strategy of fruit consumption is known. In this study, as there were species that behaved as predators of seeds, it was necessary to associate the consumption strategy adopted with the number of visits in order to estimate the quantity and quality of fruit dispersal (Schupp, 1993). Despite S. similis having been previously reported as a seed disperser (Faustino and Machado, 2006), its omnivorous diet and the fact that it acted as seed predator in most foraging bouts reduced its dispersal potential. The consumption strategy as an indicator of dispersal quality demonstrates that the effectiveness of the dispersal agent depends both on the quantity and quality of dispersal Schupp (1993).

The predominant use of the "Swallower" strategy by $L$. hasslerianum visitors implies greater probability of seed dispersal (Schupp, 1993). The technique of handling the fruit, besides the morphologic adaptations of the frugivore bird, influences the number and types of consumed fruits (Blake and Loiselle, 1992). The number of consumed fruits can be a result of foraging tactics (Kantak, 1979). In L. hasslerianum, the use of the "Stalling" strategy implies the collection of a single fruit, which demanded considerable more energy for the bird but could have the benefit of avoiding agonistic interactions and predation. The advantage for the plant is that the flight foraging tactic will lead to greater movement of the frugivores wich can disperse the seeds away from the parent plant.

Dispersers' species differ in relation to the importance given to the fruit in their diet and in the choice of fruits (Schupp, 1993). The preference depends on the accessibility of the fruits, distance and several factors that affect costs (Levey et al., 1984). Moreover, variations in the abundance and size of the birds (Rodrigues, 1995) will contribute to differences in the visitation (Schupp, 1993) and dispersal rates (Castiglioni et al., 1995).

The fact that L. hasslerianum is mainly visited by A. galeata can improve dispersion chances and reproductive success. Antilophia galeata is an endemic bird of the Cerrado region, frugivorous, and part of a small group of species $(9 \%)$ totally dependent on the forest environment (Bagno and Marinho-Filho, 2001). Frugivores, such as A. galeata, may be efficient dispersers because they spend less time and energy foraging than other birds with different diet types and habitat specialization (Foster, 1977).

However, A. galeata is a territorial bird which may reduce dispersal success of $L$. hasslerianum, because males define and defend the territory with a central area of approximately one hectare (Marini and Cavalcanti, 1992). Territorial species are able to obtain high gains for long periods, with relatively low foraging efficiency, when the environment is favourable. This would render less efficient fruit dispersal.

In the case of L. hasslerianum, the territorial behaviour of A. galeata should be a limiting factor for dispersion, since it would maintain the seeds inside a restricted area of the forest understory. However, omnivorous birds, exploring other plants and flying actively among physiognomies of the Cerrado area could transport seeds of L. hasslerianum out of forest habitats and to environments where the germination success and establishment would be smaller or null. 
Acknowledgements - We thank Ivan Schiavini, José C. SouzaSilva, José F. Ribeiro, Miguel Marini and the anonymous referees for their suggestions on the manuscript. We thank Marcela Yamamoto for help us with the EstimateS program.

\section{References}

ANDRADE, MA., 1997. Aves silvestres. Belo Horizonte: Líttera Maciel Ltda. 175 p.

ANTAS, PT. and CAVALCANTI, RB., 1988. Aves comuns do Planalto Central. Brasília: Editora da Universidade de Brasília. $238 \mathrm{p}$.

ARANTES, AA., 2002. Florística, fitossociologia e fenologia do estrato herbáceo-arbustivo de um gradiente florestal no Triângulo Mineiro. Rio Claro: Universidade Estadual Paulista. 213 p. Tese de Doutorado.

ARGEL-DE-OLIVEIRA, MM., CASTIGLIONI, GDA. and SOUZA, SD., 1996. Comportamento alimentar de aves frugívoras em Trema micrantha (Ulmaceae) em duas áreas alteradas do sudeste brasileiro. Ararajuba, vol. 4, no. 1, p. 51-55.

BAGNO, MA. and MARINHO-FILHO, J., 2001. A avifauna do Distrito Federal: uso de ambientes abertos e florestais e ameaças. In RIBEIRO, JF., FONSECA, CEL. and SOUZASILVA, JC. (Eds.). Cerrado: caracterização e recuperação de Matas de Galeria. Brasília: EMBRAPA. p. 495-528.

BLAKE, JG. and LOISELLE, BA., 1992. Fruits in the diets of Neotropical migrants birds in Costa Rica. Biotropica, vol. 24, no. 2a, p. 200-210.

CASTIGLIONI, GDA., CUNHA, LST. and GONZAGA, LP., 1995. Ramphocelus bresilius como dispersor de sementes de plantas da restinga de Barra de Marica, estado do Rio de Janeiro (Passeriformes: Emberizidae). Ararajuba, vol. 3, no. 1, p. 94-99.

DUBS, B., 1992. Birds of southwestern Brazil. Küsnacht: Betrona-Verlag. 164p.

FAUSTINO, TC. and MACHADO, CG., 2006. Frugivoria por aves em uma área de campo rupestre na Chapada da Diamantina, BA. Revista Brasileira de Ornitologia, vol. 14, no. 2, p. 137-143.

FOSTER, MS., 1977. Ecological and nutritional effects of food scarcity on a tropical frugivorous bird and its fruit source. Ecology, vol. 58, no. 1, p. 73-85.

GALETTI, M. and PIZO, MA., 1996. Fruit eating by birds in a forest fragment in southeastern Brazil. Ararajuba, vol. 4, no. 2, p. 71-79.

GENTRY, AH. and DODSON, C., 1987. Contribution of nontrees to species richness of a tropical rain forest. Biotropica, vol. 19 , no. 2, p. 149-156.

GENTRY, AH. and EMMONS, LH., 1987. Geographical variation in fertility, phenology, and composition of the understory of Neotropical forests. Biotropica, vol. 19, no. 3, p. 216-227.

GREENBERGER, R., 1981. The abundance and seasonality of forest canopy birds on Barro Colorado Island, Panama. Biotropica, vol. 13, no. 4, p. 241-251.
GUEDES, MC., MELO, VA. and GRIFFTH, JJ., 1997. Uso de poleiros artificiais e ilhas de vegetação por aves dispersoras de sementes. Ararajuba, vol. 5, no. 2, p. 229-232.

HERRERA, CM., 1982. Seasonal variation in the quality of fruits and difuse coevolution between plants and avian dispersers. Ecology, vol. 63, no. 3, p. 773-785.

KANTAK, GE., 1979. Observations on some fruit-eating birds in Mexico. Auk, vol. 96, no. 1, p. 183-186.

LAMBERT, FR. and MARSHALL, AG., 1991. Keystone characteristics of bird-dispersed Ficus in a Malaysian lowland rain forest. Journal of Ecology, vol. 79, no. 3, p. 793-809.

LEVEY, DJ., MOERMOND, TC. and DENSLOW, JS., 1984. Fruit choice in neotropical birds: the effect of distance between fruits on preference patterns. Ecology, vol. 65, no. 3, p. $844-850$.

MARINI, MA., 1992. Foraging behavior and diet of helmeted manakin. Condor, vol. 94, no. 1, p. 151-158.

MARINI, MA. and CAVALCANTI, RB., 1992. Mating system of the helmeted manakin (Antilophia galeata) in Central Brazil. Auk, vol. 109, no. 4, p. 911-913.

MELO, C., 2003. Disponibilidade quantitativa e qualitativa de frutos para avifauna associada ao sub-bosque de fisionomias florestais do bioma Cerrado. Brasília: Universidade de Brasília. 163 p. Tese de Doutorado.

MELO, C., BENTO, EC. and OLIVEIRA, PE., 2003. Frugivory and dispersal of Faramea cyanea (Rubiaceae) in cerrado woody plant formations. Revista Brasileira de Biologia $=$ Brazilian Journal of Biology, vol. 63, no. 1, p. 1-8.

MIKICH, SB., 2001. Frugivoria e dispersão de sementes em uma pequena reserva isolada do estado do Paraná. Curitiba: Universidade Federal do Paraná. 160 p. Tese de Doutorado.

MOERMOND, TC. and DENSLOW, JS., 1983. Fruit choice in Neotropical birds: effects of fruit type and accessibility on selectivity. Journal of Animal Ecology, vol. 52, no. 2, p. 407-420.

MOERMOND, TC. and DENSLOW, JS., 1985. Neotropical avian frugivores: patterns of behavior, morphology, and nutrition, with consequences for fruit selection. Ornithology monographs, vol. 36, p. 865-897.

MOTTA-JÚNIOR, JC. and LOMBARDI, JA., 1990. Aves como agentes dispersores da copaíba (Copaifera langsdorfii, Caesalpinaceae) em São Carlos, Estado de São Paulo. Ararajuba, vol. 1, no. 1, p. 105-106.

MURALI, KS., 1997. Patterns of seed size, germination and seed viability of tropical tree species in Southern India. Biotropica, vol. 29 , no. 3 , p. 271-279.

OLIVEIRA, PEAM. and PAULA, FR., 2001. Fenologia e biologia reprodutiva de plantas de Matas de Galeria. In RIBEIRO, JF., FONSECA, CEL. and SOUZA-SILVA, JC. (Eds). Cerrado: caracterização e recuperação de Matas de Galeria. Brasília: EMBRAPA. p. 303-332.

RIBEIRO, RD., 2001. Ecologia alimentar de aves do subbosque de mata atlântica de Minas Gerais. Belo Horizonte: Universidade Federal de Minas Gerais. 91p. Dissertação de Mestrado. 
RODRIGUES, M., 1995. Spatial distribution and food utilization among tanagers in southeastern Brazil (Passeriformes - Emberezidae). Ararajuba, vol. 3, no. 1, p. 27-32.

ROSA, R., LIMA, SC. and ASSUNÇÃO, WL., 1991. Abordagem preliminar das condições climáticas de Uberlândia (MG). Sociedade \& Natureza, vol. 3, no. 1, p. 91-108.

SCHIAVINI, I., 1992. Estrutura das comunidades arbóreas de mata de galeria da Estação Ecológica do Panga (Uberlândia, $M G$ ). Campinas: Universidade de Campinas. 139p. Tese de Doutorado.

SCHIAVINI, I. and ARAÚJO, GM., 1989. Considerações sobre a vegetação da Reserva Ecológica do Panga, Uberlândia, MG. Sociedade \& Natureza, vol. 1, no. 1, p. 60-66.

SCHUPP, EW., 1993. Quantity, quality and the effectiveness of seed by animals. Vegetatio, vol. 107-108, no. 1, p. 15-29.
SICK, H., 1987. Ornitologia brasileira: uma introdução. Brasília: Editora da Universidade de Brasília. 827p.

SILVA-JÚNIOR, MC., FELFILI, JM., WALTER, BMT., NOGUEIRA, PE., REZENDE, AV., MORAIS, RO. and NÓBREGA, MGG., 2001. Análise da flora arbórea de Matas de Galeria no Distrito Federal: 21 levantamentos. In RIBEIRO, JF., FONSECA, CEL. and SOUZA-SILVA, JC. (Eds). Cerrado: caracterização e recuperação de Matas de Galeria. Brasília: EMBRAPA. p. 143-208

SNOW, DW., 1971. Evolutionary aspects of fruit-eating by birds. Ibis, vol. 113, no. 2, p. 194-202.

TALORA, DC. and MORELLATO, PC., 2000. Fenologia de espécies arbóreas em floresta de planície litorânea do sudeste do Brasil. Revista Brasileira de Botânica, vol. 23, no. 1, p. 13-26.

ZAR, JH., 1999. Biostatistical analysis. Rio de Janeiro: Prentice-Hall do Brasil. 663p. 